\title{
HIP ASSESSMENT: A COMPARISON OF NINE DIFFERENT METHODS
}

\author{
Gunnar Andersson, Göteborg, Sweden \\ From the Department of Orthopaedic Surgery II,* University of Göteborg
}

The careful assessment of results is necessary to evaluate different methods of treatment and the need for operation. In hip surgery this is difficult because of the many factors involved: the indication for operation, the patient's motivation, the actual operation to be done and the treatment thereafter, the period of observation and the selection of cases. Therefore it is important to have an objective and reliable method of assessment based on simple and welldefined criteria. It is the purpose of this paper to compare different methods of assessment on the same series of patients, in order to show the different results and to emphasise the importance of uniformity in publishing results.

Some authors express only a personal opinion, without defining their criteria; others use tables giving grades to mark different results. Grades given to a patient before or after treatment are absolute values. They enable one to make comparisons between hips, and

TABLE I

Systems of Assessment without Separate Functional Evaluation

\begin{tabular}{|ll|c|c|c|}
\hline & & Pain & Movement & Walking \\
\hline Merle d'Aubigné (1950) & $\cdot$ & $0-6$ & $0-6$ & $0-6$ \\
\hline Judet and Judet (1952). & $\cdot$ & $1-6$ & $1-6$ & $1-6$ \\
\hline Stinchfield et al. (1957) & $\cdot$ & $1-6$ & $1-6$ & $1-6$ \\
\hline
\end{tabular}

patients, and form a basis for individual grading. The difference between grades before and after operation are relative values, called "amelioration rates", which measure the change as a result of treatment. Thus, to get a complete understanding of results any method of assessment should measure both values.

With the increased interest in arthroplasties a number of methods of assessment have been developed. The precise details of these methods can be found in the original papers.

A numerical system by Ferguson and Howorth (1931) was improved by Merle d'Aubigné (1950) and further modified by Judet and Judet (1952) (Table I). They graded the results using three figures, one for pain, one for movement and one for walking. A total of six points was given to each and the figures were added to give an overall result. The tables differ mainly in the assessment of movement; the Judet system measures the sum of degrees of motion in the different planes, whereas Merle d'Aubigné based his value on the amount of flexion and abduction. Furthermore, he allowed for a 0 possibility in all assessments. Stinchfield, Cooperman and Shea (1957) used the Judet method but set the standards higher (Table I).

\footnotetext{
*Head: Professor Bertil Stener, Göteborg, Sweden.
} 
Another rating scale was suggested by the American Academy of Orthopaedic Surgeons (Goodwin 1968 and Table II). It is not based on numerical values but considers pain, range of movement and walking. It has been used with slight modifications by several authors.

In 1954 a research group on arthroplasty of the hip was appointed by the British Orthopaedic Association to make a critical survey of the results of these operations, and a method of assessment was presented by Shepherd (1954). It was based on pain, active movement (Gade's mobility index 1947), functional activity, and the patient's own assessment (Table III).

TABLE II

System of Assessment Suggested by the American Academy of Orthopaedic Surgeons (Goodwin 1963)

\begin{tabular}{|l|l|}
\hline Excellent & $\begin{array}{l}\text { Patients are free of pain, can walk as far as they wish without assistance and have at least } \\
75 \text { per cent range of motion. }\end{array}$ \\
\hline Good. & $\begin{array}{l}\text { Patients have only minimal pain and ambulate independently with one or two canes. The } \\
\text { range of motion is over } 50 \text { per cent. }\end{array}$ \\
\hline Fair. & $\begin{array}{l}\text { Patients have moderate pain on weight-bearing and can walk only short distances with } \\
\text { assistance. The range of motion is less than } 50 \text { per cent. }\end{array}$ \\
\hline Poor. & Patients are confined to a wheel chair with only minimal weight-bearing. \\
\hline Failure . & Patients have severe pain at rest and are not able to bear weight. \\
\hline
\end{tabular}

TABLE III

Methods of Assessment with Separate Functional Evaluation

\begin{tabular}{|c|c|c|c|c|c|c|c|}
\hline & & & Pain & Movement & $\begin{array}{l}\text { Functional } \\
\text { activity }\end{array}$ & $\begin{array}{l}\text { Patients'own } \\
\text { assessment }\end{array}$ & $\begin{array}{l}\text { Radiographic } \\
\text { appearance }\end{array}$ \\
\hline Shepherd (1954) . & . & $\cdot$ & $1-5$ & $0-100$ & $0-28$ & $1-4$ & \\
\hline Danielsson (1964) . & . & $\cdot$ & $0-5$ & $0-100$ & $0-28$ & & \\
\hline Öhman et al. (1969) & . & . & $0-5$ & $0-100$ & $0-28$ & & \\
\hline Andersson and Möller & Niels & $n(1972)$ & $0-5$ & $0-100$ & $0-27$ & & \\
\hline \multirow[t]{2}{*}{ Iselin (1968) . } & . & $\cdot$ & $0-100$ & $0-50$ & $0-60$ & $0-40$ & $0-50$ \\
\hline & & & & & & Gait & $\begin{array}{l}\text { Absence of } \\
\text { deformity }\end{array}$ \\
\hline Larson (1963) & . & . & $0-35$ & $0-10$ & $0-35$ & $0-10$ & $0-10$ \\
\hline Harris (1969) & . & . & $0-44$ & $0-5$ & $\begin{array}{r}0-47 \\
(0-14\end{array}$ & $0-33)$ & $0-4$ \\
\hline
\end{tabular}

The main improvement on earlier schemes was the functional assessment table, by use of which the patient's everyday activities as well as his ability to walk could be estimated. Danielsson (1964 and Table III) modified the method of grading pain to allow distinction between various types of pain, such as on starting, walking or resting, and slightly changed the definition for functional assessment. The patient's own assessment was excluded. Iselin (1968 and Table III) completely changed the numerical evaluation and added the radiographic appearance. Öhman, Björkegren and Fahlström (1969 and Table III) and later Andersson and Möller-Nielsen (1972 and Tables III and IV) further modified the system into a rating scale that allowed a single overall value and improved the statistical analysis.

In order to provide generally applicable systems for various hip disabilities and methods of treatment Larson (1963 and Table III) and Harris (1969 and Table III) introduced two new 
rating scales. Using numerical classification with a maximum of 100 points, they considered pain, function, gait, freedom from deformity, and motion. Allowing different numbers of points for different considerations, they emphasised the importance of function and pain. Whereas Larson considered gait separately and assessed many different everyday activities, Harris emphasised gait as a part of the functional assessment. The two tables also differ in the evaluation of movement, Larson measuring the sum of degrees of motion, while Harris multiplied the number of degrees of motion in each plane by an index factor.

TABLE IV

Assessment Table Used by ANDersson ANd Möller-Nielsen (1972)

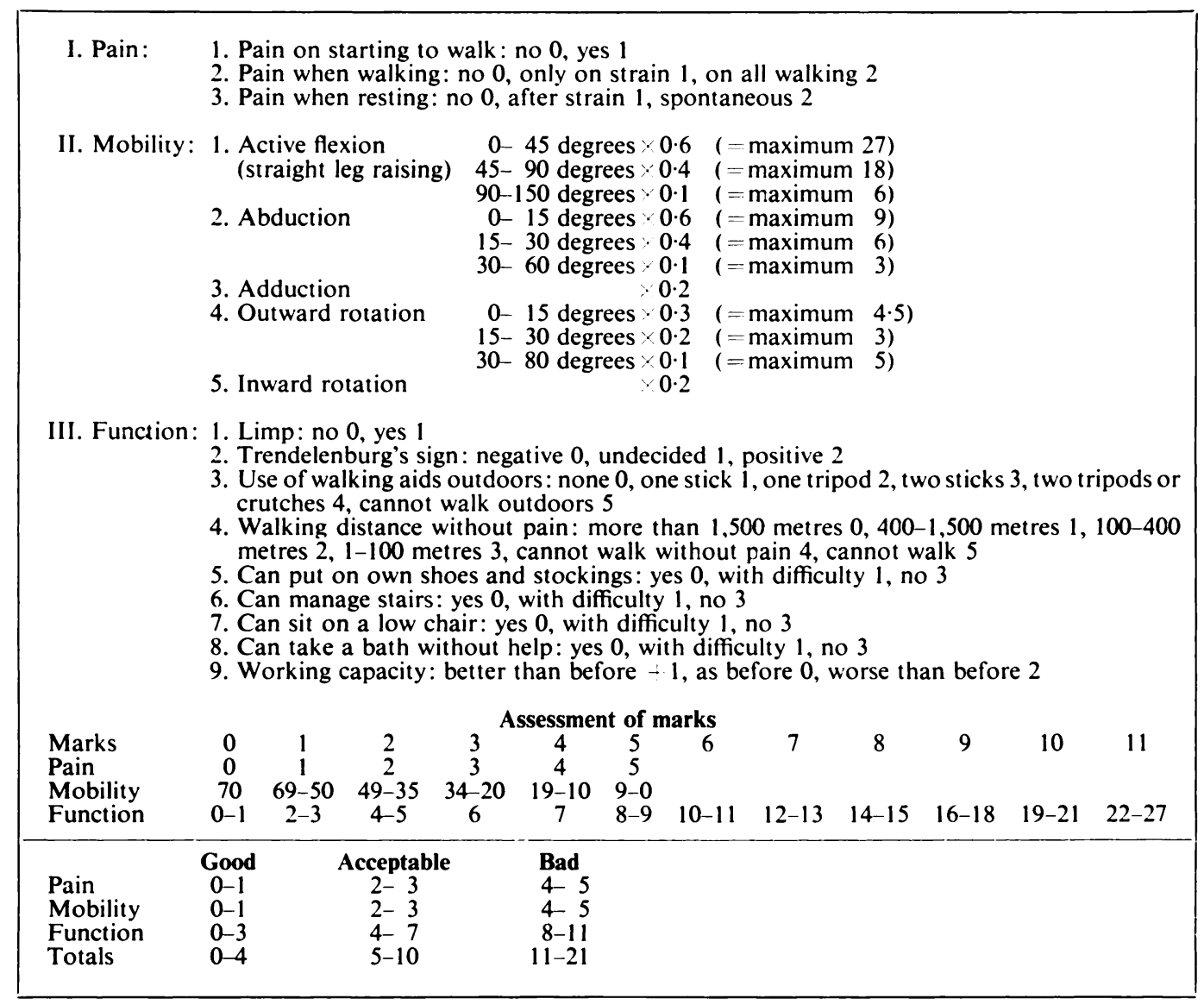

\section{MATERIAL AND METHOD}

In 1969 an attempt was made to study late results and complications in a series of seventyseven hips treated by Moore arthroplasty (Andersson and Möller-Nielsen 1972). The patients were examined and assessed according to nine different methods, but that of Danielsson was not used because it did not give results comparable to the others. Because of the lack of definitely comparable radiographs Iselin's method was also excluded. To simplify statistical work only three grades of result were used. In the good group were included very good and excellent results of some evaluation methods, and in the bad group very bad and failures. Every patient was asked for his own opinion. None of the patients was operated upon by either of the investigators.

VOl. 54 B, NO. 4, NOVEMBER 1972 


\section{RESULTS}

The results are shown in Table V. The variation in results is obvious and enables a differentiation of assessment systems into five statistically different groups (Table VI).

The patient's own opinion is listed in Table VII. The results here are significantly less good than the results as obtained by the methods of Judet, Stinchfield, the American Academy of Orthopaedic Surgeons and Shepherd, and over-optimistic as compared to those assessed by Merle d'Aubigné.

\section{TABLE V}

Results in Percentage Using Different Systems of Assessment on the Same Selection of Patients

\begin{tabular}{|c|c|c|c|c|c|c|c|c|c|}
\hline & $\begin{array}{c}\text { Judet } \\
\text { and } \\
\text { Judet }\end{array}$ & $\begin{array}{l}\text { Stinchfield } \\
\text { et al. }\end{array}$ & $\begin{array}{c}\text { Merle } \\
\text { d'Aubigné }\end{array}$ & $\begin{array}{c}\text { American } \\
\text { Academy of } \\
\text { Orthopaedic } \\
\text { Surgeons }\end{array}$ & Shepherd & $\begin{array}{l}\text { Öhman } \\
\text { et al. }\end{array}$ & Larson & Harris & $\begin{array}{c}\text { Andersson } \\
\text { and } \\
\text { Möller- } \\
\text { Nielsen }\end{array}$ \\
\hline Good & $97 \cdot 5$ & $62 \cdot 5$ & 35 & $51 \cdot 5$ & 49 & 30 & 49 & 36 & 36 \\
\hline Fair & $2 \cdot 5$ & $28 \cdot 5$ & 17 & 43 & 33 & 40 & 13 & 24 & 38 \\
\hline $\mathrm{Bad}$ & 0 & 9 & 48 & $6 \cdot 5$ & 18 & 30 & 38 & 40 & 26 \\
\hline
\end{tabular}

TABLE VI

Statistically Different Groups of Methods of Assessment

\begin{tabular}{|cc|}
\hline Group & Authors \\
\hline 1 & Judet and Judet \\
\hline 2 & $\begin{array}{c}\text { Stinchfield } \text { et al. } \\
\text { American Academy of } \\
\text { Orthopaedic Surgeons }\end{array}$ \\
\hline 3 & Shepherd \\
\hline
\end{tabular}

\begin{tabular}{|c|c|}
\hline Group & Authors \\
\hline & $\begin{array}{c}\text { Larson } \\
\text { Ohman } \text { et al. } \\
4\end{array}$ \\
& $\begin{array}{c}\text { Andersson and Möller-Nielsen } \\
\text { Harris }\end{array}$ \\
\hline 5 & Merle d'Aubigné \\
\hline
\end{tabular}

TABLE VII

The Patient's Own Opinion

\begin{tabular}{|l|c|c|}
\hline & $\begin{array}{c}\text { Number of } \\
\text { patients }\end{array}$ & Per cent \\
\hline Good $\cdot$ & 51 & 67 \\
\hline Acceptable & 6 & 8 \\
\hline Bad. & 20 & 25 \\
\hline
\end{tabular}

\section{SUMMARY}

1. The various methods of assessing the results of hip arthroplasties have been investigated.

2. The different results obtained by using different methods are very significant.

3. The importance of achieving a generally agreed assessment is obvious. 


\section{REFERENCES}

Andersson, G., and Möller-Nielsen, J. (1972): Results after Arthroplasty of the Hip with Moore's Prosthesis. Acta Orthopaedica Scandinavica (in press).

Danielsson, L. G. (1964): Incidence and Prognosis of Coxarthrosis. Acta Orthopaedica Scandinavica, Supplementum 66.

Ferguson, A. B., and Howorth, M. B. (1931): Slipping of the Upper Femoral Epiphysis. Journal of the American Medical Association, 97, 1867.

Gade, H. G. (1947): A Contribution to the Surgical Treatment of Osteoarthritis of the Hip-Joint: a Clinical Study. Acta Chirurgica Scandinavica, Supplementum 120, 37.

Goodwin, R. A. (1968): The Austin Moore Prosthesis in Fresh Femoral Fractures. American Journal of Orthopedic Surgery, 10, 40.

HARRIS, W. H. (1969): Traumatic Arthritis of the Hip after Dislocation and Acetabular Fractures: Treatment by Mold Arthroplasty. Journal of Bone and Joint Surgery, 51-A, 737.

Iselin, M. (1968): Metallprothesen nach Schenkelhalsfrakturen. Nachuntersuchung von 75 Prothesen. Archiv für orthopädische und Unfall-Chirurgie, 63, 52.

JUDET, R., and JUDET, J. (1952): Technique and Results with the Acrylic Femoral Head Prosthesis. Journal of Bone and Joint Surgery, 34-B, 173.

Larson, C. B. (1963): Rating Scale for Hip Disabilities. Clinical Orthopaedics and Related Research, $31,85$.

Merle D’Aubigné, R. (1950): Traitment chirurgical de la coxarthrie, p. 240. $4^{e}$ Congrès International de Chirurgie Orthopédique, Amsterdam 13-18 Septembre, 1948. Bruxelles: Société Internationale de Chirurgie Orthopédique et de Traumatologie.

Öhman, U., BJörkegren, N.-Å., and Fahlström, G. (1969): Fracture of the Femoral Neck. A Five-year Follow-up. Acta Chirurgica Scandinavica, 135, 27.

ShePHERD, M. M. (1954): Assessment of Function after Arthroplasty of the Hip. Journal of Bone and Joint Surgery, 36-B, 354.

Stinchfield, F. E., Cooperman, B., and Shea, C. E., Jun. (1957): Replacement of the Femoral Head by Judet or Austin Moore Prosthesis. Journal of Bone and Joint Surgery, 39-A, 1043.

VOL. 54 B, NO. 4, NOVEMBER 1972 